\title{
Effect of Different Alkali-assisted Deposition Precipitation Methods on the Durability of Three-way Catalysts
}

\author{
FAN Jun ${ }^{1}$, JIANG Xue ${ }^{2}$, JIAO Yi $^{2}$, CHEN Yusheng ${ }^{1}$, WANG Jianli ${ }^{1}$, CHEN Yaoqiang ${ }^{1,2}$ \\ (1. College of Chemistry, Sichuan University, Chengdu 610064, China; 2. Institute of New Energy and Low-Carbon Technology, \\ Sichuan University, Chengdu 610064, China)
}

\begin{abstract}
The aging treatment always brings about severe deactivation of three-way catalysts (TWCs) so that improving the durability is one goal of TWCs design. In this work, $\mathrm{Pt} / \mathrm{Ce}_{0.4} \mathrm{Zr}_{0.5} \mathrm{La}_{0.05} \mathrm{Pr}_{0.05} \mathrm{O}_{2}(\mathrm{Pt} / \mathrm{CZ}) \mathrm{TWCs}$ were prepared by two different alkali-assisted deposition precipitation method, urea or ammonia. The effects of different alkali-assisted on the physicochemical properties, catalytic activity and durability were analyzed. It was found that the $\mathrm{Pt} / \mathrm{CZ}$ catalyst prepared by urea-assisted deposition precipitation method (UDP) had poor aging resistance but the $\mathrm{Pt} / \mathrm{CZ}$ catalyst prepared by ammonia-assisted (ADP) showed better anti-aging ability. Based on the results of XRD, $\mathrm{CO}$ adsorption, XPS and $\mathrm{H}_{2}$-TPR, comparatively larger particle size of Pt species and stronger interaction for ADP make it more difficult to sinter together during the aging treatment, which is favorable for maintaining catalytic activity. Therefore, the ADP catalyst shows a bright future for industrialization.
\end{abstract}

Key words: three-way catalysts; deposition precipitation; alkali-assisted; durability

Three-way catalysts (TWCs) are one of the most important catalysts in purifying exhaust gas from gasoline powered vehicles ${ }^{[1-2]}$, which are able to effectively convert hazardous carbon monoxide $(\mathrm{CO})$, nitrogen oxides $\left(\mathrm{NO}_{x}\right)$, hydrocarbons $(\mathrm{HC})$ to harmless carbon dioxide $\left(\mathrm{CO}_{2}\right)$, water $\left(\mathrm{H}_{2} \mathrm{O}\right)$ and nitrogen $\left(\mathrm{N}_{2}\right)$ simultaneously ${ }^{[3-4]}$. However, aging is the main cause of catalyst deactivation due to the serious influence on the structural and textural properties, metal dispersion, oxygen storage capacity (OSC) and redox ability ${ }^{[5-6]}$. It is necessary to design TWCs with high stability to meet increasingly durability requirement ${ }^{[7-8]}$. Researchers have done a lot of work to improve the thermal stability of TWCs ${ }^{[9-10]}$, suppressing phase transformation and preventing the sintering of active noble metal. No matter which strategy, the typical formulation of TWCs is unchanged because of their preferable poisoning resistance and higher thermal stability ${ }^{[10-11]}$. Generally, changing the preparation method is a simple and easy route to improve the durability of TWCs ${ }^{[12-13]}$.

The deposition precipitation method is one of the main preparation methods for industrial catalysts, which is done in the presence of an existing support, and a precursor solution usually forms metal hydroxides by injection of the precipitant ${ }^{[14]}$. Thomas, et al. ${ }^{[15]}$ used deposition precipitation method to prepare $\mathrm{Co} / \mathrm{TiO}_{2}$ catalysts using urea hydrolysis or ammonia evaporation. Moreau, et al. ${ }^{[16]}$ prepared $\mathrm{Au} / \mathrm{TiO}_{2}$ catalyst by deposition precipitation method with $\mathrm{NaOH}$ as precipitant. The deposition precipitation method has been widely used in the preparation of catalysts, but it is rarely used in the preparation of noble metal TWCs. Therefore, it is valuable to study the deposition precipitation method for the preparation of TWCs.

In the present work, we have prepared ceria-zirconiasupported platinum (Pt/CZ) catalysts with different alkaliassisted deposition precipitation method, and a $\mathrm{Pt} / \mathrm{CZ}$ catalyst prepared by impregnation method as reference catalyst. The effect of different alkali-assisted deposition precipitation methods on the stability of TWCs were investigated.

\section{Experimental}

\subsection{Catalyst preparation}

The metal precursor was $\mathrm{H}_{2} \mathrm{PtCl}_{6}(0.10 \mathrm{~g} / \mathrm{mL})$ aqueous solution and the loading content of $\mathrm{Pt}$ was $1 \mathrm{wt} \%$. The

Received date: 2020-06-29; Revised date: 2020-09-17; Published online: 2020-10-23

Foundation item: National Natural Sciece Foundation of China (22072097); Sichuan Science and Technology Program (2019YFS0498)

Biography: FAN Jun (1996-), female, Master candidate. E-mail: fj960117@163.com

范 君(1996-), 女, 硕士研究生. E-mail: fj960117@163.com

Corresponding author: JIAO Yi, professor. E-mail: jiaoyiscu@163.com; WANG Jianli, professor. E-mail: wangjianli@scu.edu.cn 焦 毅, 教授. E-mail: jiaoyiscu@163.com; 王健礼, 教授. E-mail: wangjianli@scu.edu.cn 
support material, a mixed oxide of $\mathrm{CeO}_{2}-\mathrm{ZrO}_{2}-\mathrm{La}_{2} \mathrm{O}_{3}-\mathrm{Pr}_{2} \mathrm{O}_{5}$ (the mass ratio of $40 / 50 / 5 / 5, \mathrm{CZ}$ ) was supplied by Rhodia Company. The benchmark $\mathrm{Pt} / \mathrm{CZ}$ was prepared by traditional impregnation method (IM). The catalyst prepared by deposition-precipitation method assisted with urea (molar ratio of urea $/ \mathrm{Pt}=50$ ) was labeled as UDP. Another catalyst prepared by deposition-precipitation method assisted with ammonia at $\mathrm{pH}=9$ was labeled as ADP. All samples were dried in an oven at $90{ }^{\circ} \mathrm{C}$ for $1 \mathrm{~d}$ and calcined at $550{ }^{\circ} \mathrm{C}$ for $3 \mathrm{~h}$ in air. The as-prepared powders were sprinkled onto cordierite to obtain the monolithic catalyst with a loading capacity of $(160 \pm 5) \mathrm{g} / \mathrm{L}$. Afterwards the monolithic catalysts were calcined at $550{ }^{\circ} \mathrm{C}$ for $3 \mathrm{~h}$ in air to obtain the fresh catalysts. The fresh catalysts were hydrothermal treated in $10 \mathrm{vol} \% \mathrm{H}_{2} \mathrm{O} /$ air at $750{ }^{\circ} \mathrm{C}$ for $13 \mathrm{~h}$ to obtain aged catalysts, which were labeled as IM-a, UDP-a and ADP-a, respectively.

\subsection{Catalyst characterization}

The textural properties of the catalysts were obtained by Quantachrome automated surface area and pore size analyzer (Autosorb SI). The powder X-ray diffraction (XRD) patterns were recorded on Philips Company (PW 1730). The dispersion of Pt species was performed on $\mathrm{CO}$ pulse adsorption and Fourier transform infrared spectrometer (FT-IR, Thermo Nicolet 6700). X-ray photoelectron spectroscopy (XPS) experiments were carried out on an electron spectrometer (XSAM-800). Hydrogen-temperature programmed reduction $\left(\mathrm{H}_{2}-\mathrm{TPR}\right)$ was performed in a tubular quartz microreactor and recorded by thermal conductivity detector (TCD).

\subsection{Activity tests}

The catalytic performance were evaluated using a fixed-bed continuous flow reactor by passing through a simulated gasoline engine exhaust gas mixture, which was composed of $\mathrm{CO}\left(4600 \times 10^{-6}\right), \mathrm{C}_{3} \mathrm{H}_{6}\left(220 \times 10^{-6}\right), \mathrm{C}_{3} \mathrm{H}_{8}$ $\left(110 \times 10^{-6}\right), \mathrm{H}_{2}\left(1533 \times 10^{-6}\right)$, NO $\left(1250 \times 10^{-6}\right), \mathrm{CO}_{2}(10 \%)$, $\mathrm{H}_{2} \mathrm{O}(10 \%), \mathrm{O}_{2}\left(3600 \times 10^{-6}\right)$ and $\mathrm{N}_{2}$ (balance gas). The gas hourly space velocity (GHSV) was controlled at $5 \times 10^{4} \mathrm{~h}^{-1}$.

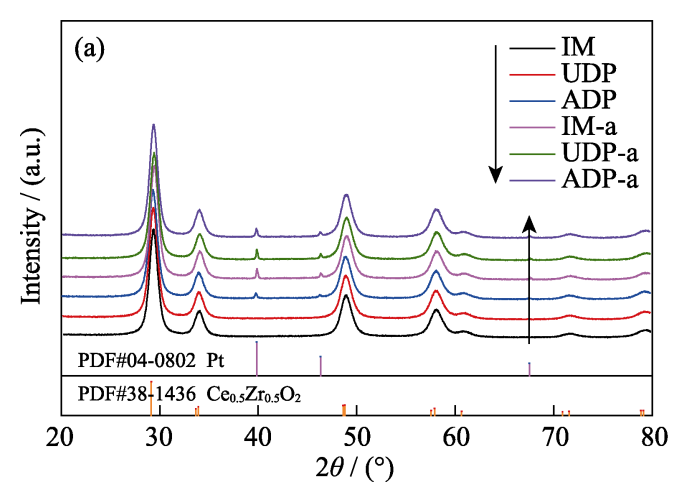

Fig. 1 XRD patterns of fresh and aged samples (a) and the comparison of their relative intensities of $\mathrm{Pt}$ (111) based on the strongest peak of support (b)

\section{Results and discussion}

\subsection{Textural and structural characterization}

The textural parameters of the support and catalysts are listed in Table 1. It can be seen that the specific surface area and pore volume of samples are similar with each other. However, the average pore radii of UDP-a and ADP-a are smaller than that of IM-a. This may be attributed to that the Pt species are more likely to enter the small pores of support in the preparation of UDP and ADP. The presence of Pt in the small pores is conducive to maintaining the pores in the aging process ${ }^{[17]}$.

The X-ray diffraction patterns and relative intensity of Pt (111) are shown in Fig. 1. It is observed from Fig. 1(a) that the diffraction peaks of all samples are characteristic of cubic $\mathrm{CeO}_{2}-\mathrm{ZrO}_{2}(\mathrm{CZ})$ phase ${ }^{[18]}$. There are no peaks of Pt or $\mathrm{PtO}_{x}$ in IM and UDP, which may be attributed to the good dispersion of Pt species on support. However, it is clear to find out that the diffraction peaks of Pt in ADP, confirming the existence of larger Pt particles in ADP. After aging, the peaks identified as Pt phase are observed for all samples due to the agglomeration of noble metal. The relative intensity of $\mathrm{Pt}$ (111) peak of these catalysts are shown in Fig. 1(b). The order of diffraction peak intensity can be recorded as UDP-a > IM-a > ADP-a. This indicates that Pt particles are the smallest in the ADP-a.

Table 1 Textural and structural parameters of the support and samples

\begin{tabular}{lccc}
\hline Samples & $\begin{array}{c}\text { Surface area/ } \\
\left(\mathrm{m}^{2} \cdot \mathrm{g}^{-1}\right)\end{array}$ & $\begin{array}{c}\text { Pore volume/ } \\
\left(\mathrm{mL} \cdot \mathrm{g}^{-1}\right)\end{array}$ & $\begin{array}{c}\text { Average pore } \\
\text { radius/nm }\end{array}$ \\
\hline IM & 60 & 0.23 & 7.5 \\
UDP & 63 & 0.22 & 7.5 \\
ADP & 61 & 0.23 & 7.7 \\
IM-a & 49 & 0.24 & 9.4 \\
UDP-a & 50 & 0.22 & 7.6 \\
ADP-a & 53 & 0.25 & 7.7 \\
CZLP & 64 & 0.25 & 8.7 \\
\hline
\end{tabular}

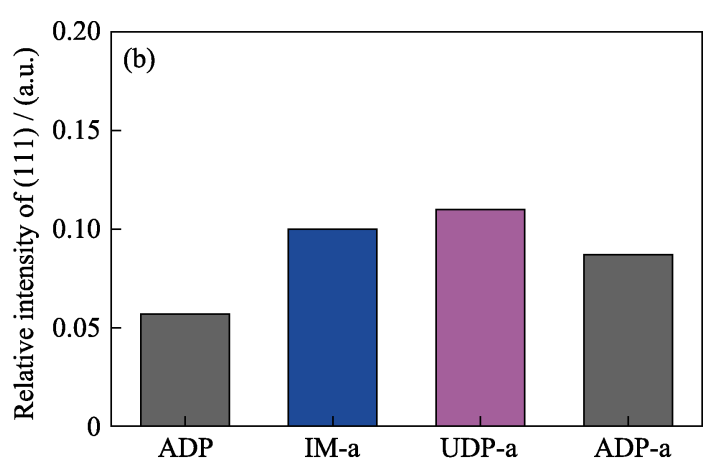




\subsection{CO chemisorption results}

The dispersion of $\mathrm{Pt}$ species was evaluated by $\mathrm{CO}$ pulse adsorption method, and the obtained results are depicted in Fig. 2(a). The dispersion of Pt species for fresh samples follow the order of UDP > IM > ADP which coincides with the XRD results. For the aged samples, the dispersion of Pt species sharply declines owing to the aggregation of noble metal particles.

The CO adsorption experiment was also performed on an FT-IR equipment and the obtained CO-FTIR spectrum were presented in Fig. 2(b, c). The IR band exhibited in figures are assigned to $\mathrm{CO}$ species linearly adsorbed on $\mathrm{Pt}^{0[19]}$. For the fresh samples, the intensity of band decreased with an order of IM $\approx$ UDP > ADP, which reflects the dispersion of Pt species to some extent ${ }^{[20]}$. As for aged samples, compared with fresh samples, the band strength of UDP-a decreases more greatly, while that of ADP-a samples decreases more slightly, which indicates that ADP owns good hydrothermal stability. This is consistent with the results of XRD analysis.

\subsection{XPS analysis}

X-ray photoelectron spectroscopy (XPS) experiment was performed to clarify the surface elemental states of samples. The relative amounts of $\mathrm{Ce}, \mathrm{O}$ and $\mathrm{Pt}$ are listed in Table 2, and the obtained spectra of O1s, Ce3d and Pt4f are illustrated in Fig. 3. The spectra of O1s (Fig. 3(a, d)) are composed of two characteristic peaks with the corresponding binding energy (BE) values of 529.2 and $531.2 \mathrm{eV}$. One at $529.2 \mathrm{eV}$ is denoted as lattice oxygen $\left(\mathrm{O}_{\text {latt }}\right)$, and the other at $531.2 \mathrm{eV}$ is attributed to surface adsorbed oxygen $\left(\mathrm{O}_{\mathrm{ads}}\right)^{[21]}$. The spectra of Ce3d (Fig. 3(b, e)) are deconvoluted into eight peaks corresponding to four pairs of spin-orbit doublets. The peaks labeled as v, v", $\mathrm{v}$ "' and $\mathrm{u}, \mathrm{u}$ ", u" , are assigned to $\mathrm{Ce}^{4+}$, and an additional doublet $\left(v^{\prime}, u^{\prime}\right)$ are arisen from $\mathrm{Ce}^{3+}$ species $^{[20]}$. For the XPS spectra of Pt4f (c, f), the peak at $70.7 \mathrm{eV}$ is assigned to $\mathrm{Pt}^{0}$ and that at $72.4 \mathrm{eV}$ is ascribed to $\mathrm{PtO}$. Moreover, the peaks locating at $74.0 \mathrm{eV}$ is attributed to $\mathrm{PtO}_{2}{ }^{[22]}$.
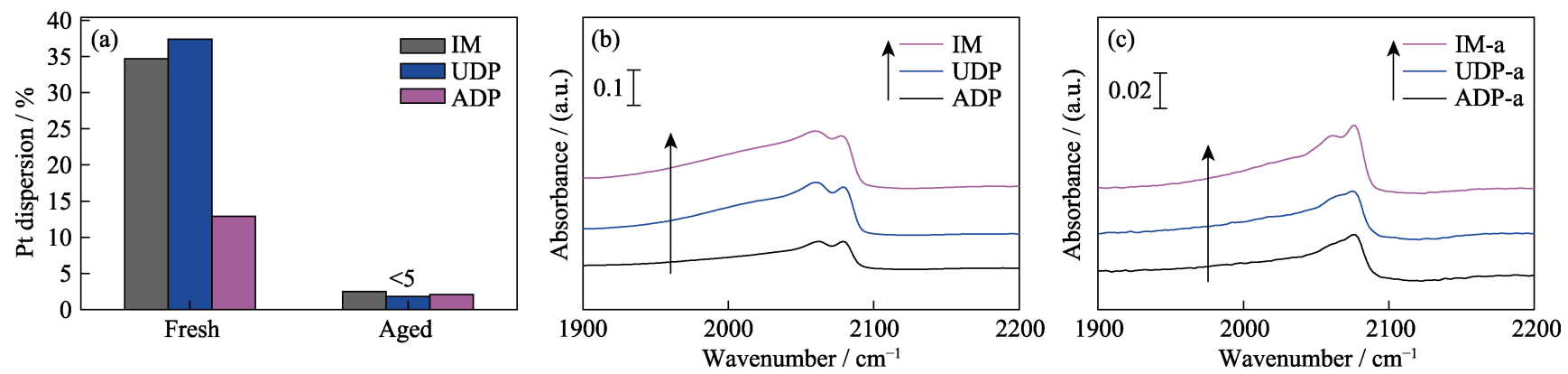

Fig. 2 Pt dispersion of samples measured by CO-chemisorption method (a) and FT-IR spectra of $\mathrm{CO}$ absorbed on the fresh (b) and aged (c) samples
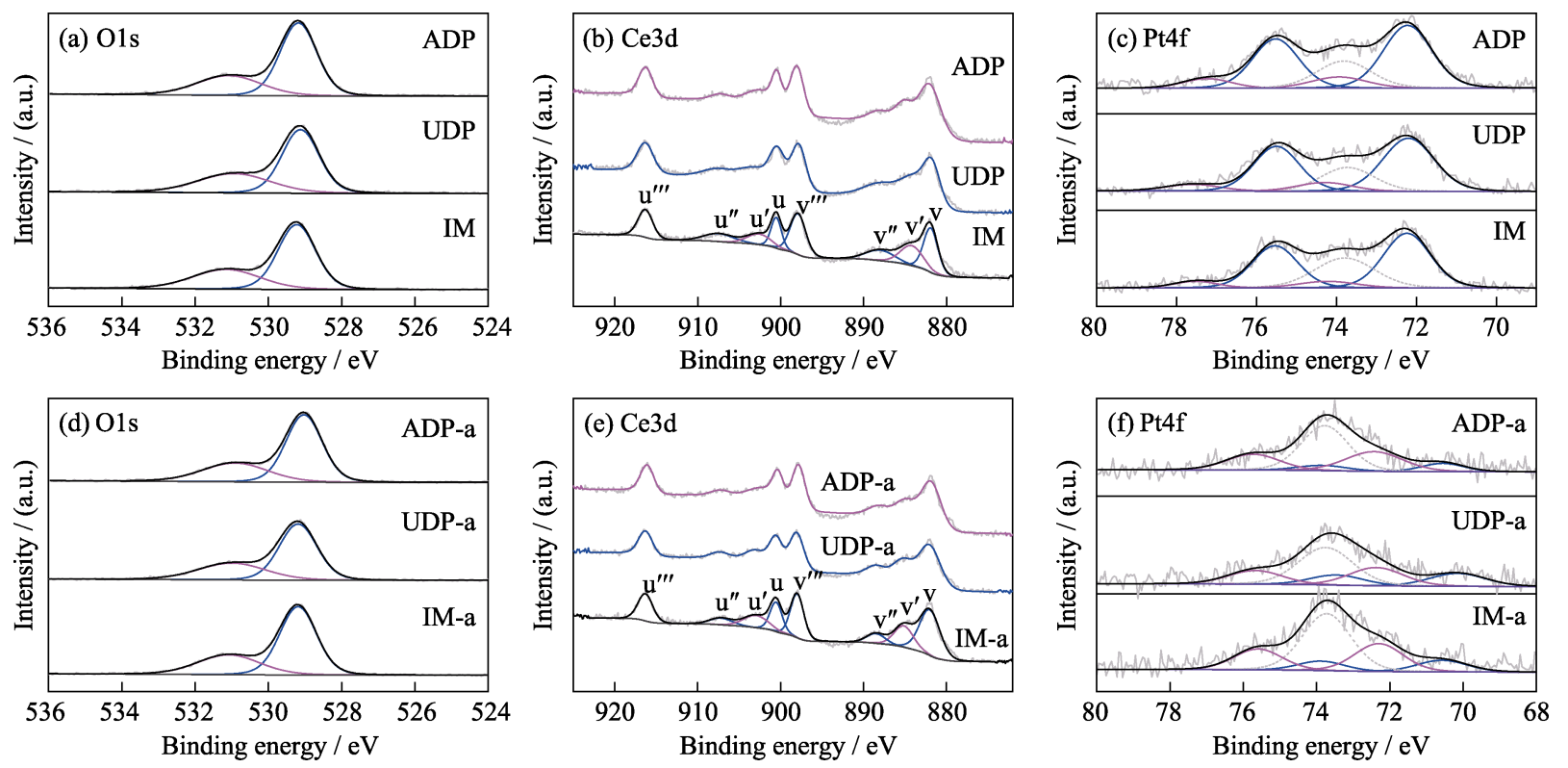

Fig. 3 XPS spectra of O1s (a, d), Ce3d (b, e) and Pt4f (c, f) for fresh (a-c) and aged (d-f) samples 
As shown in Fig. 3(a, d), $\mathrm{O}_{\mathrm{ads}}$ and $\mathrm{O}_{\text {latt }}$ exist in all samples. The ratio of $\mathrm{O}_{\text {ads }} / \mathrm{O}$ for fresh samples is in the sequence of UDP > IM > ADP, but the aged samples exhibit a different sequence with an order of UDP-a $>$ ADP-a > IM-a. It is observed slight decrease of $\mathrm{O}_{\text {ads }}$ for IM and UDP, but slight increase for ADP. As well known, more $\mathrm{O}_{\mathrm{ads}}$ can enhance catalytic activity under vehicle exhaust atmosphere.

$\mathrm{Ce}^{3+}$ and $\mathrm{Ce}^{4+}$ coexist on the surface. The analysis of the relative ratio of $\mathrm{Ce}^{3+}$ reveal that conspicuous decline of the ratio of $\mathrm{Ce}^{3+} / \mathrm{Ce}$ occurs after aging in case of UDP, slight decline for IM-a, while slight increase for ADP-a. The change trend is consistent with that of $\mathrm{O}_{\text {ads. }}$. Because the existence of $\mathrm{Ce}^{3+}$ has an important influence on oxygen vacancy which is conducive to adsorbing more oxygen from the gas ${ }^{[23]}$. Therefore, the oxygen vacancies in ADP are well maintained during hydrothermal aging treatment, which is favorable for keeping redox property as well as the catalytic performance.

Regarding Pt species, it is easy to detect that platinum species mainly exist in oxide state for the existence of $\mathrm{Pt}-\mathrm{O}-\mathrm{Ce}$ interaction as well ${ }^{[24]}$. It can be detected Table 2 that the value of $\mathrm{Pt}^{4+} / \mathrm{Pt}$ follow the order of ADP $>$ UDP $>$ IM. ADP has the highest $\mathrm{Pt}^{4+} / \mathrm{Pt}$ ratio which can be explained by the stronger interaction between $\mathrm{Pt}$ and support. The stronger interaction is conductive to maintaining Pt species at a more stable state. After aging, the surface concentration of $\mathrm{Pt}$ decreases to some extent. The platinum species mainly exist as $\mathrm{Pt}^{2+}$ and $\mathrm{Pt}^{0}$ that $\mathrm{PtO}_{2}$ decompose to $\mathrm{Pt}$ metal under oxidizing conditions at above $600{ }^{\circ} \mathrm{C}^{[3]}$. What should be mentioned is that UDP-a has higher relative percent of $\mathrm{Pt}^{0}$, which suggests that the stability of UDP-a is poor. However, ADP-a has relative higher ratio of $\mathrm{Pt}^{2+}$, which also proves that ADP has a better ability to resist hydrothermal treatment.

In conclusion, from the analysis of XPS data, ADP prepared by ammonia-assisted deposition precipitation method possess stronger metal-support interaction to resist aging treatment.

\section{$2.4 \mathrm{H}_{2}$-TPR studies}

The $\mathrm{H}_{2}$-TPR profiles are displayed in Fig. 4. It is observed that IM has two reduction peaks. One peak at $198{ }^{\circ} \mathrm{C}$ is assigned to the reduction of $\mathrm{PtO}_{x}$ and $\mathrm{Ce}$ species that are effectively promoted by noble metal for the spillover effect ${ }^{[25]}$. The other peak at $380{ }^{\circ} \mathrm{C}$ is assigned to the reduction of a very low percent of surface un-activated oxygen. UDP also has two reduction peaks. The first peak at $174{ }^{\circ} \mathrm{C}$ is lower than that of IM, implying that UDP possess better reducibility than IM due to the better dispersion of Pt species. Attention should be paid to ADP. In the range of low temperature, ADP has a main reduction peak and two shoulder peaks with the corresponding temperature at 106, 150 and $174{ }^{\circ} \mathrm{C}$. Combining the analysis above, the lower reduction temperature can be ascribed to the stronger interaction in ADP. In addition, the three reduction peaks can be ascribed to the reduction of the $\mathrm{PtO}_{x}$ species and Ce species with different degree of interaction. This can be explained as a consequence of the existence of small and big particles in ADP. The reason for the smaller area of reduction peak is that the big Pt particles have a weaker promoting effect on the support.

After hydrothermal aging treatment, the reduction peaks for aged catalysts shift to higher temperature due to the sintering and agglomeration of active components. It should be noted that the temperature of the main reduction peak of UDP-a shift from $174{ }^{\circ} \mathrm{C}$ to $202{ }^{\circ} \mathrm{C}$, while that of ADP-a only shift from $150{ }^{\circ} \mathrm{C}$ to $164{ }^{\circ} \mathrm{C}$. The result suggests that the ADP undergone slighter sintering and the redox properties were well maintained, which proved the better hydrothermal stability in case of ADP.

Table 2 Surface elemental state ratio derived from by XPS

\begin{tabular}{clcccc}
\hline Sample & $\begin{array}{c}\mathrm{Pt}^{0} / \mathrm{Pt} \\
\text { ratio }\end{array}$ & $\begin{array}{c}\mathrm{Pt}^{2+} / \mathrm{Pt} \\
\text { ratio }\end{array}$ & $\begin{array}{c}\mathrm{Pt}^{4+} / \mathrm{Pt} \\
\text { ratio }\end{array}$ & $\begin{array}{c}\mathrm{O}_{\text {ads }} / \mathrm{O} \\
\text { ratio }\end{array}$ & $\begin{array}{c}\mathrm{Ce}^{3+} / \mathrm{Ce} \\
\text { ratio }\end{array}$ \\
\hline IM & 0 & 0.871 & 0.129 & 0.354 & 0.217 \\
UDP & 0 & 0.851 & 0.149 & 0.374 & 0.240 \\
ADP & 0 & 0.831 & 0.169 & 0.324 & 0.201 \\
IM-a & 0.302 & 0.698 & 0 & 0.329 & 0.195 \\
UDP-a & 0.421 & 0.579 & 0 & 0.350 & 0.187 \\
ADP-a & 0.234 & 0.766 & 0 & 0.336 & 0.214 \\
\hline
\end{tabular}
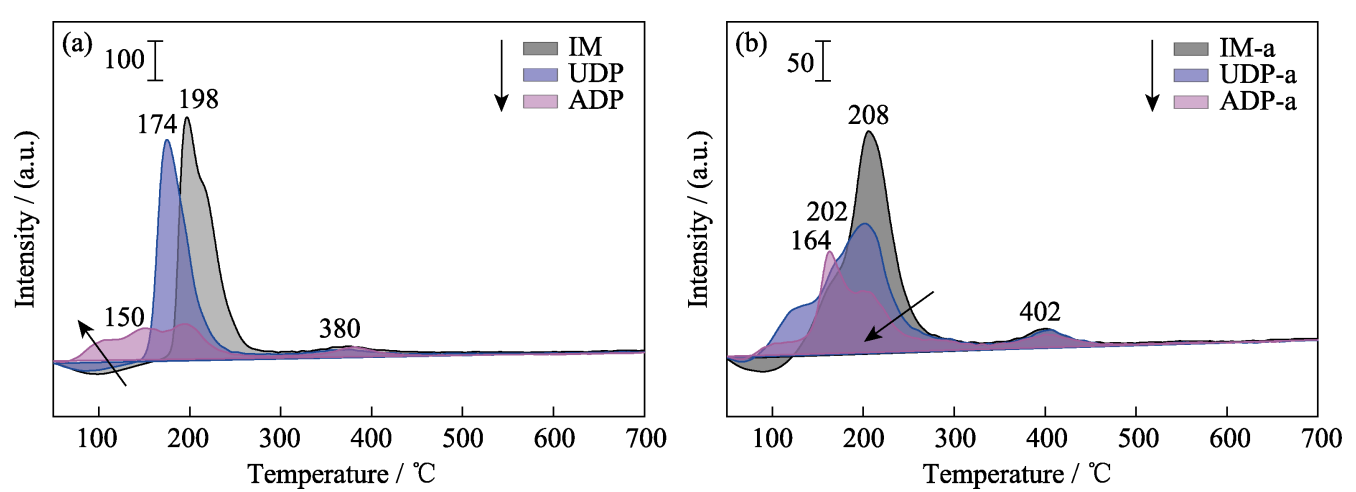

Fig. $4 \mathrm{H}_{2}$-TPR profiles of the fresh (a) and aged (b) samples 


\subsection{Catalytic performance}

The conversion curves of $\mathrm{CO}, \mathrm{NO}, \mathrm{C}_{3} \mathrm{H}_{8}$ and $\mathrm{C}_{3} \mathrm{H}_{6}$ for all series of samples are depicted in Fig. 5. For fresh catalysts, UDP exhibits better $\mathrm{CO}$ conversion activity than the reference sample IM due to the higher dispersion of $\mathrm{Pt}$ species and higher content of $\mathrm{O}_{\mathrm{ads}}$. ADP exhibits worse catalytic activity for all pollutions due to the worse dispersion of Pt species.

As for the aged samples, the catalytic activities are in the sequence of ADP-a>IM-a>UDP-a. The activity results exhibit converse sequence with the fresh samples. In order to compare durability carefully, the light-off temperature $\left(T_{50}\right.$, the temperature where pollutions obtained $50 \%$ conversion), and the $\Delta T$ (defined as $T_{50}$ of aged samples $-T_{50}$ of fresh samples) are summarized in Table 3. $\Delta T$ is an important parameter to evaluate the stability of TWCs. The $T_{50}$ of UDP-a shifts to higher temperature with $\Delta T$ of $87{ }^{\circ} \mathrm{C}$ for $\mathrm{CO}, 54{ }^{\circ} \mathrm{C}$ for $\mathrm{NO}$, $55{ }^{\circ} \mathrm{C}$ for $\mathrm{C}_{3} \mathrm{H}_{8}$ and $59{ }^{\circ} \mathrm{C}$ for $\mathrm{C}_{3} \mathrm{H}_{6}$. This may be ascribed to that the smaller particles are easily agglomerated together, which leads to the sharp decline of dispersion of Pt species and catalytic activity. A similar situation is also found in IM-a, which $T_{50}$ has an increase of 41, 44, $43,44{ }^{\circ} \mathrm{C}$ respectively. Whereas the $\Delta T$ of $T_{50}$ over ADP is $16{ }^{\circ} \mathrm{C}$ for $\mathrm{CO}, 17{ }^{\circ} \mathrm{C}$ for $\mathrm{NO}, 22{ }^{\circ} \mathrm{C}$ for $\mathrm{C}_{3} \mathrm{H}_{8}$ and $18{ }^{\circ} \mathrm{C}$ for $\mathrm{C}_{3} \mathrm{H}_{6}$. This indicates that ADP has better ability to maintain catalytic activity against hydrothermal treatment. ADP possess bigger Pt particles and stronger interaction in essence, which are favorable for enhancing the catalytic stability.

\section{Conclusions}

We have prepared $\mathrm{Pt} / \mathrm{CZ}$ catalysts by two different alkali-assisted deposition precipitation method. The effects of two different alkali on the physicochemical properties, catalytic activity and durability of the catalysts were investigated.

Some important results and conclusions are presented as follows: (1) UDP showed poor aging resistance that the catalytic activity decreased seriously after hydrothermal aging treatment. (2) ADP exhibited good anti-aging ability, with little physicochemical properties and catalytic activity changed after aging. (3) The different alkaliassisted deposition precipitation methods have an important influence on the initial particle size of $\mathrm{Pt}$ and interaction in the catalyst, resulting in a great difference in durability.

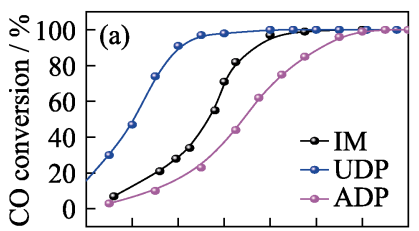
$12{ }^{\circ}+4^{\circ}, 6^{\circ} 8^{\circ} 2_{20} 0_{2} 2_{2} 4^{\circ} 2^{\circ}$ Temperature $/{ }^{\circ} \mathrm{C}$

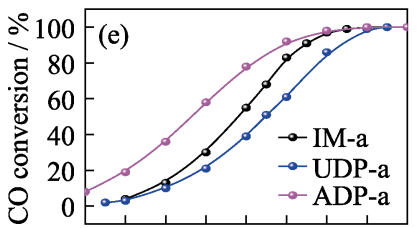

$14 \mathrm{O}_{1} \mathrm{O}_{1} \mathrm{O}_{2} \mathrm{O}_{2} \mathrm{O}_{2} \mathrm{O}_{2} 4 \mathrm{O}_{2} \mathrm{O}_{2} \mathrm{O}_{2} \mathrm{O}_{3} \mathrm{O}^{\circ}$ Temperature $/{ }^{\circ} \mathrm{C}$

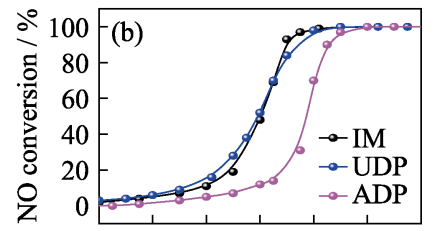

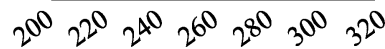

Temperature $/{ }^{\circ} \mathrm{C}$

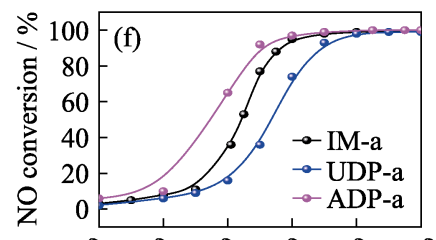

$2^{60^{\circ}} \quad 20^{\circ} \quad 30^{\circ} \quad 320 \quad 34^{\circ} \quad 36^{\circ}$

Temperature $/{ }^{\circ} \mathrm{C}$

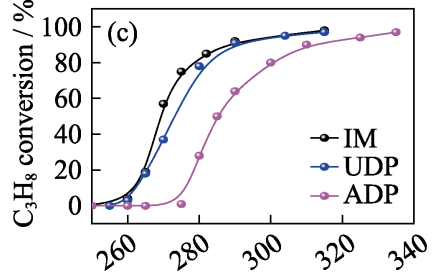

Temperature $/{ }^{\circ} \mathrm{C}$

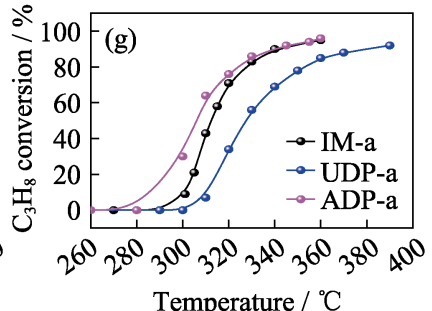

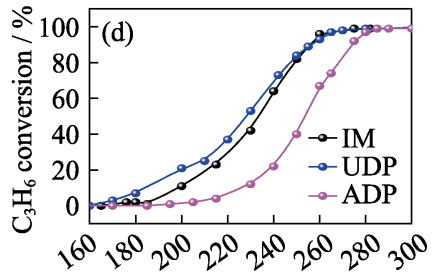

Temperature $/{ }^{\circ} \mathrm{C}$

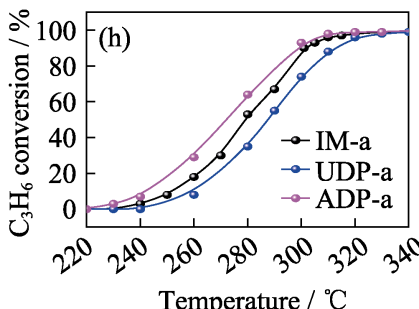

Fig. 5 Conversion curves of $\mathrm{CO}, \mathrm{NO}, \mathrm{C}_{3} \mathrm{H}_{8}$ and $\mathrm{C}_{3} \mathrm{H}_{6}$ over the fresh (a-d) and aged (e-h) samples, respectively

Table 3 Light-off $\left(T_{50}\right)$ temperature and $\Delta T$ for three-way catalytic reactions over catalysts

\begin{tabular}{|c|c|c|c|c|c|c|c|c|}
\hline \multirow{2}{*}{ Sample } & \multicolumn{2}{|c|}{$\mathrm{CO}$} & \multicolumn{2}{|c|}{$\mathrm{NO}$} & \multicolumn{2}{|c|}{$\mathrm{C}_{3} \mathrm{H}_{8}$} & \multicolumn{2}{|c|}{$\mathrm{C}_{3} \mathrm{H}_{6}$} \\
\hline & $T_{50} /{ }^{\circ} \mathrm{C}$ & $\Delta T /{ }^{\circ} \mathrm{C}$ & $T_{50} /{ }^{\circ} \mathrm{C}$ & $\Delta T /{ }^{\circ} \mathrm{C}$ & $T_{50} /{ }^{\circ} \mathrm{C}$ & $\Delta T /{ }^{\circ} \mathrm{C}$ & $T_{50} /{ }^{\circ} \mathrm{C}$ & $\Delta T /{ }^{\circ} \mathrm{C}$ \\
\hline IM & 174 & - & 260 & - & 269 & - & 234 & - \\
\hline UDP & 142 & - & 259 & - & 273 & - & 228 & - \\
\hline ADP & 187 & - & 277 & - & 284 & - & 254 & - \\
\hline IM-a & 215 & 41 & 304 & 44 & 312 & 43 & 278 & 44 \\
\hline UDP-a & 229 & 87 & 313 & 54 & 328 & 55 & 287 & 59 \\
\hline ADP-a & 203 & 16 & 294 & 17 & 306 & 22 & 272 & 18 \\
\hline
\end{tabular}




\section{References:}

[1] LI G F, WANG Q Y, ZHAO B, et al. A new insight into the role of transition metals doping with $\mathrm{CeO}_{2}-\mathrm{ZrO}_{2}$ and its application in Pd-only three-way catalysts for automotive emission control. Fuel, 2012, 92: 360-368.

[2] HANEDA M, SHINODA K, NAGANE A, et al. Catalytic performance of rhodium supported on ceria-zirconia mixed oxides for reduction of NO by propene. Journal of Catalysis, 2008, 259: 223-231.

[3] NAGAI Y, HIRABAYASHI T, DOHMAE K, et al. Sintering inhibition mechanism of platinum supported on ceria-based oxide and Pt-oxide-support interaction. Journal of Catalysis, 2006, 242: 103-109.

[4] ZHAN Z C, LIU X J, HE H, et al. Fabrication of a flower-like $\mathrm{Pd} / \mathrm{CeO}_{2}$ material with improved three-way catalytic performance. Journal of Rare Earths, 2013, 31: 750-758.

[5] FERNANDESA D M, SCOFIELDA C F, NETO A A, et al. Thermal deactivation of $\mathrm{Pt} / \mathrm{Rh}$ commercial automotive catalysts. Chemical Engineering Journal, 2010, 160: 85-92.

[6] ESCHEMANN T O, BITTER J H, JONG K P. Effect of thermal ageing on the structure and catalytic activity of $\mathrm{Pd} / \mathrm{CeO}_{2}$ prepared using arc-plasma process. Catalysis Science Technology, 2014, 4: 2990-2996.

[7] YOON D Y, KIM Y J, LIM J H, et al. Thermal stability of Pd-containing $\mathrm{LaAlO}_{3}$ perovskite as a modern TWC. Journal of Catalysis, 2015, 330: 71-83.

[8] TANABE T, NAGAI Y, DOHMAE K, et al. Sintering and redispersion behavior of $\mathrm{Pt}$ on $\mathrm{Pt} / \mathrm{MgO}$. Journal of Catalysis, 2008, 257: $117-124$.

[9] WANG J H, CHEN H, HU Z C, et al. A review on the Pd-based three-way catalyst. Catalysis Reviews, 2014, 57: 79-144.

[10] HE J J, WANG H X, ZHENG T T, et al. Thermally induced deactivation and the corresponding strategies for improving durability in automotive three-way catalysts. Johnson Matthey Technology Review, 2016, 60: 196-203.

[11] LI H M, LAN L, CHEN S H, et al. Preparation of $\mathrm{Ce}_{x} \mathrm{Zr}_{1-x} \mathrm{O}_{2}$ with combined composition for improved Pd-only three-way catalyst. Journal of Inorganic Materials, 2018, 33(7): 798-804.

[12] WU Q F, CUI Y J, ZHANG H L, et al. Preparation of ceria-zirconia mixed oxides with improved thermal stability for three-way catalysts by a modified co-precipitation method. Journal of Inorganic Materials, 2017, 32(3): 331-336.

[13] FAN J, CHEN Y S, JIANG X, et al. A simple and effective method to synthesize $\mathrm{Pt} / \mathrm{CeO}_{2}$ three-way catalysts with high activity and hydrothermal stability. Journal of Environmental Chemical Engineering, 2020, 8: 104236-104243.

[14] MUNNIK P, JONGH P E, JONG K P. Recent developments in the synthesis of supported catalysts. Chemical Reviews, 2015, 115: 6687-6718.

[15] ESCHEMANN T O, BITTER J H, JONG K P. Effects of loading and synthesis method of titania-supported cobalt catalysts for Fischer-Tropsch synthesis. Catalysis Today, 2014, 228: 89-95.

[16] MOREAU F, BOND G C. Gold on titania catalysts, influence of some physicochemical parameters on the activity and stability for the oxidation of carbon monoxide. Applied Catalysis A: General, 2006, 302: 110-117.

[17] PACELLA M, GARBUjO A, FABRO J, et al. PGM-free $\mathrm{CuO} / \mathrm{LaCoO}_{3}$ nanocomposites: new opportunities for TWC application. Applied Catalysis B: Environmental, 2018, 227: 446-458.

[18] CHENG T Q, WANG J L, WANG S N, et al. Citric acid induced promoted dispersion of $\mathrm{Pt}$ on the support and enhanced catalytic activities for a Pt-based catalyst. Applied Surface Science, 2017, 426: $745-754$.

[19] BAZIN P, SAUR O, LAVALLEY J C, et al. FT-IR study of CO adsorption on $\mathrm{Pt} / \mathrm{CeO}_{2}$ : characterisation and structural rearrangement of small Pt particles. Physical Chemistry Chemical Physics, 2005, 7: 187-194.

[20] SHEN M Q, LÜ L F, WANG J Q, et al. Study of Pt dispersion on Ce based supports and the influence on the $\mathrm{CO}$ oxidation reaction. Chemical Engineering Journal, 2014, 255: 40-48.

[21] FAN J, WU X D, YANG L, et al. The SMSI between supported platinum and $\mathrm{CeO}_{2}-\mathrm{ZrO}_{2}-\mathrm{La}_{2} \mathrm{O}_{3}$ mixed oxides in oxidative atmosphere. Catalysis Today, 2007, 126: 303-312.

[22] PENG R S, LI S J, SUN X B, et al. Size effect of Pt nanoparticles on the catalytic oxidation of toluene over $\mathrm{Pt} / \mathrm{CeO}_{2}$ catalysts. Applied Catalysis B: Environmental, 2018, 220: 462-470.

[23] FAN J, WU X D, WU X D, et al. Thermal ageing of Pt on low-surface-area $\mathrm{CeO}_{2}-\mathrm{ZrO}_{2}-\mathrm{La}_{2} \mathrm{O}_{3}$ mixed oxides: effect on the OSC performance. Applied Catalysis B: Environmental, 2008, 81: $38-48$.

[24] WU X D, FAN J, RAN R, et al. Effect of preparation methods on the structure and redox behavior of platinum-ceria-zirconia catalysts. Chemical Engineering Journal, 2005, 109: 133-139.

[25] ZHANG H L, WANG J L, ZHANG Y H, et al. A study on $\mathrm{H}_{2}$-TPR of $\mathrm{Pt} / \mathrm{Ce}_{0.27} \mathrm{Zr}_{0.73} \mathrm{O}_{2}$ and $\mathrm{Pt} / \mathrm{Ce}_{0.27} \mathrm{Zr}_{0.70} \mathrm{La}_{0.03} \mathrm{O}_{x}$ for soot oxidation. Applied Surface Science, 2016, 377: 48-55.

\title{
不同碱辅助的沉积沉淀法对三效催化剂稳定性的影响
}

\author{
范君 ${ }^{1}$, 江 雪 ${ }^{2}$, 焦毅 ${ }^{2}$, 陈宇圣 ${ }^{1}$, 王健礼 ${ }^{1}$, 陈耀强 ${ }^{1,2}$ \\ (四川大学 1. 化学学院; 2. 新能源与低碳技术研究院, 成都 610064)
}

\begin{abstract}
摘 要: 老化处理会导致三效催化剂(TWCs)严重失活, 因此提高催化剂的耐久性能是 TWCs 设计的目标。本工作采 用不同碱辅助的沉积沉淀法, 即尿素辅助沉积沉淀法和氨水辅助沉积沉淀法制备了 $\mathrm{Pt} / \mathrm{Ce}_{0.4} \mathrm{Zr}_{0.5} \mathrm{La}_{0.05} \mathrm{Pr}_{0.05} \mathrm{O}_{2}(\mathrm{Pt} / \mathrm{CZ})$ 三效催化剂, 分析了不同碱对催化剂物理化学性质、催化活性和耐久性的影响。结果表明, 尿素辅助沉积沉淀法 (UDP)制备的 $\mathrm{Pt} / \mathrm{CZ}$ 催化剂的抗老化性能较差, 而氨水辅助沉积沉淀法(ADP)制备的催化剂的抗老化能力较强。 XRD, CO 吸附, XPS 和 $\mathrm{H}_{2}$-TPR 表征结果表明, ADP 中较大的 Pt 颗粒以及更强的金属载体相互作用使 ADP 在老化 过程中烧结程度较低, 有利于维持催化活性。因此, ADP 催化剂具有一定的工业应用前景。
\end{abstract}

关 键 词: 三效催化剂; 沉积沉淀; 碱辅助; 稳定性

中图分类号: O643 文献标志码: A 